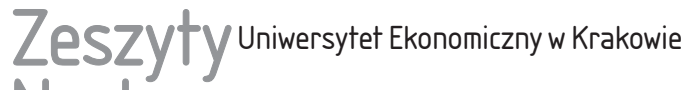 Naukowe
}

\section{Modele doboru metod w rozwiązywaniu problemów zarządzania w ujęciu G. Nadlera*}

\section{Streszczenie}

Zwiększanie efektywności organizacji jako kategorii mieszczącej się w naukach o zarządzaniu stanowi jedno z ważniejszych wyzwań zarówno praktyków, jak i teoretyków tej dyscypliny naukowej. Odpowiedni dobór metod w rozwiązywaniu problemów zarządzania jest jednym z czynników zwiększających efektywność organizacji. Brakuje jednak wyczerpujących opracowań metodologicznych w zakresie koncepcji doboru metod w rozwiązywaniu problemów zarządzania. Koncepcja systemu idealnego G. Nadlera może służyć jako podstawa do budowy wspomnianej koncepcji. Celem niniejszego opracowania jest zaprezentowanie możliwości adaptacji koncepcji G. Nadlera w tworzeniu modeli doboru metod w rozwiązywaniu problemów zarządzania. Jako metody badawcze zastosowano dedukcję oraz analizę literatury przedmiotu. W artykule przedstawiono istotę koncepcji systemu idealnego według G. Nadlera, a następnie zaprezentowano autorską propozycję modeli idealnych koncepcji doboru metod w rozwiązywaniu problemów zarządzania. W zakończeniu zamieszczono wnioski oraz wskazano propozycję dalszych badań.

Słowa kluczowe: system idealny, dobór metod, problemy zarządzania, koncepcja G. Nadlera.

Klasyfikacja JEL: M0, M00, M1, M10, M19.

Marek Szarucki, Uniwersytet Ekonomiczny w Krakowie, Katedra Analiz Strategicznych, 31-510 Kraków, ul. Rakowicka 27, e-mail: szaruckm@uek.krakow.pl

${ }^{*}$ Niniejszy artykuł powstał w wyniku jednego z etapów badań prowadzonych w ramach projektu badawczego pt. „Model doboru metod w procesie rozwiązywania problemów zarządzania” finansowanego ze środków przyznanych przez Narodowe Centrum Nauki (nr decyzji 2014/13/B/ HS4/03452). 


\section{Wprowadzenie}

W naukach o zarządzaniu jako dyscyplinie empirycznej wiele miejsca poświęca się procesowi tworzenia oraz doskonalenia różnego rodzaju organizacji. Jednym z głównych celów tego rodzaju działań jest zwiększanie efektywności organizacji jako kategorii oceny mieszczącej się w naukach o zarządzaniu (zob. [Nalewajko 1983, Piekarz i Stabryła 1989, Cameron i Whetten 1996, Martyniak 2000, Bratnicki i Frączkiewicz-Wronka 2006, Ziębicki 2014]). Istnieje wiele kryteriów efektywności organizacji obejmujących rozmaite atrybuty organizacji. Zwiększenie efektywności organizacji jako całości wymaga zastosowania odpowiedniego systemu metodologicznego zapewniającego sprawne rozwiązywanie różnego rodzaju problemów występujących w organizacji. Jedną z tego rodzaju kwestii metodologicznych wymagających większej uwagi ze strony zarówno praktyków, jak i metodologów zarządzania jest dobór metod w rozwiązywaniu problemów zarządzania. Opracowanie kompleksowej koncepcji doboru takich metod pozwoli zwiększyć efektywność organizacji. Koncepcja systemów idealnych Geralda Nadlera stanowi dobrą podstawę do opracowania wspomnianej koncepcji metodologicznej.

Celem niniejszego artykułu jest przedstawienie możliwości zastosowania koncepcji systemów idealnych G. Nadlera w tworzeniu modeli doboru metod w rozwiązywaniu problemów zarządzania. Jako metodę badawczą zastosowano dedukcję opartą na analizie literatury z zakresu nauk o zarządzaniu. Opracowanie składa się z dwóch części. Na początku przedstawiono istotę systemu idealnego G. Nadlera w kontekście doskonalenia organizacji. Część drugą poświęcono charakterystyce modeli doboru metod w rozwiązywaniu problemów zarządzania według tego badacza. Uwagi końcowe zawierają wnioski oraz wskazanie przyszłych kierunków badań dotyczące omawianej tematyki.

\section{System idealny G. Nadlera w doskonaleniu organizacji}

W literaturze z zakresu metodologii nauk o zarządzaniu spotkać można różne podejścia badawcze do rozwiązania problemu naukowego, jakim jest poszukiwanie odpowiedzi na pytanie: jak zapewnić efektywność organizacyjną? Generalnie ujęcia tego problemu naukowego sprowadzić można do dwóch podejść metodologicznych. Pierwsze z nich zakłada identyfikowanie problemów w organizacji oraz ich rozwiązywanie. Zabiegi te prowadzą do zwiększenia efektywności organizacyjnej. W tym przypadku najczęściej stosowane metody naukowe to metoda indukcyjna i hipotetyczno-dedukcyjna [Lisiński 2016a, s. 11]. Bazują one na konkretnych przypadkach empirycznych, a zidentyfikowane problemy 
rozwiązywane są zgodnie z zasadą od szczegółu do ogółu. Drugie podejście koncentruje się na rozwiązaniu problemu efektywności organizacji poprzez identyfikację sprawdzonych rozwiązań praktycznych, ich uogólnianie oraz zastosowanie do konkretnego przypadku. Metoda naukowa stosowana w tym podejściu to metoda dedukcyjna [Ajdukiewicz 1975], w której problemy naukowe rozwiązywane są zgodnie z zasadą od ogółu do szczegółu. Metoda dedukcyjna opiera się na już sprawdzonych i zweryfikowanych faktach, dlatego nie wymaga formułowania oraz weryfikowania hipotez badawczych. W ich miejsce stosuje się tezy, które następnie są potwierdzane w toku wnioskowania logicznego wykorzystującego sprawdzone teorie. W tym punkcie artykułu przedstawiona została koncepcja będąca odzwierciedleniem podejścia metodologicznego zakładającego projektowanie i tworzenie doskonałego systemu organizacyjnego, w odróżnieniu od podejścia ulepszającego „właściwego dla tradycji taylorowskiej, eksponującej rejestrację stanu faktycznego i krytyczną ocenę istniejących faktów" [Martyniak 1987, s. 146].

Rozwój ogólnej teorii systemów oraz doświadczenia praktyczne zdobyte w obszarze przestrzennego organizowania pracy i analizy wartości stanowiły podstawę opracowania przez G. Nadlera [1967, s. 22] nowej koncepcji metodycznej. Zgodnie z założeniami koncepcja ta, znana również pod nazwą IDEALS (Ideal Design of Effective and Logical Systems), zawiera w sobie specyficzną strategię projektowania, skutecznie stosowaną w różnych obszarach organizacji działalności gospodarczej w wielu państwach w celu zwiększenia wydajności oraz rozwoju efektywności pracowników.

Podstawowe założenie budowy idealnego systemu stanowi możliwość zorganizowania w sposób efektywny badanego systemu pracy umożliwiającego osiąganie optymalnych wyników. Jest to odmienne podejście wobec tradycyjnego usprawniania poszczególnych elementów systemu pracy w badanej organizacji. Głównym celem zastosowania tej koncepcji jest zwiększenie efektywności organizacji oparte na projektowaniu i opracowaniu optymalnego systemu. Mianowicie zamiast szukania wariantów usprawniających poszczególne ,cegiełki” analizowanego systemu pracy ,poszukuje się właściwej koncepcji efektywnego zorganizowania rozpatrywanego systemu pracy", bazując na koncepcji idealnej i „zbliżając się stopniowo do koncepcji spełniającej warunki ograniczające” [Martyniak 1987, s. 147]. Podejście to zakłada stosowanie rozumowania dedukcyjnego w miejsce rozumowania indukcyjnego. $Z$ kolei postrzeganie systemu jako całości w odróżnieniu od rozpatrywania osobno jego elementów sprzyja myśleniu twórczemu i prowadzi do tzw. inspiracji heurystycznej.

Podstawą budowy oryginalnej koncepcji metodycznej jest system pracy, a jego główną funkcję stanowi cel, który powinien zostać osiągnięty za pomocą danego systemu. Ten cel uzasadnia istnienie systemu pracy postrzeganego jako 
operacyjna kombinacja zasobów ludzkich, fizycznych i finansowych, umożliwiająca transformowanie wejść (informacji, materiałów, osób) na preferowane wyjścia (wyroby lub usługi). Koncepcję G. Nadlera najlepiej wyjaśnia ilustracja graficzna w postaci trójkąta lub piramidy uwzględniająca poziomy systemów idealnych (zob. rys. 1). Podstawę tego trójkąta reprezentują koszty jednostkowe produkcji. Mogą to być również koszty produkcji całkowitej, zapotrzebowanie na materiały, powierzchnię, nakłady inwestycyjne, zasoby ludzkie lub czasochłonność produkcji. W miarę oddalania się od podstawy trójkąta do jego wierzchołka koszty jednostkowe maleją. Stanowi to podstawowe założenie metodologiczne trójstopniowego podziału koncepcji systemu idealnego G. Nadlera na: system idealny teoretyczny, system idealny perspektywiczny oraz system idealny realizowalny technologicznie (zob. rys. 1).

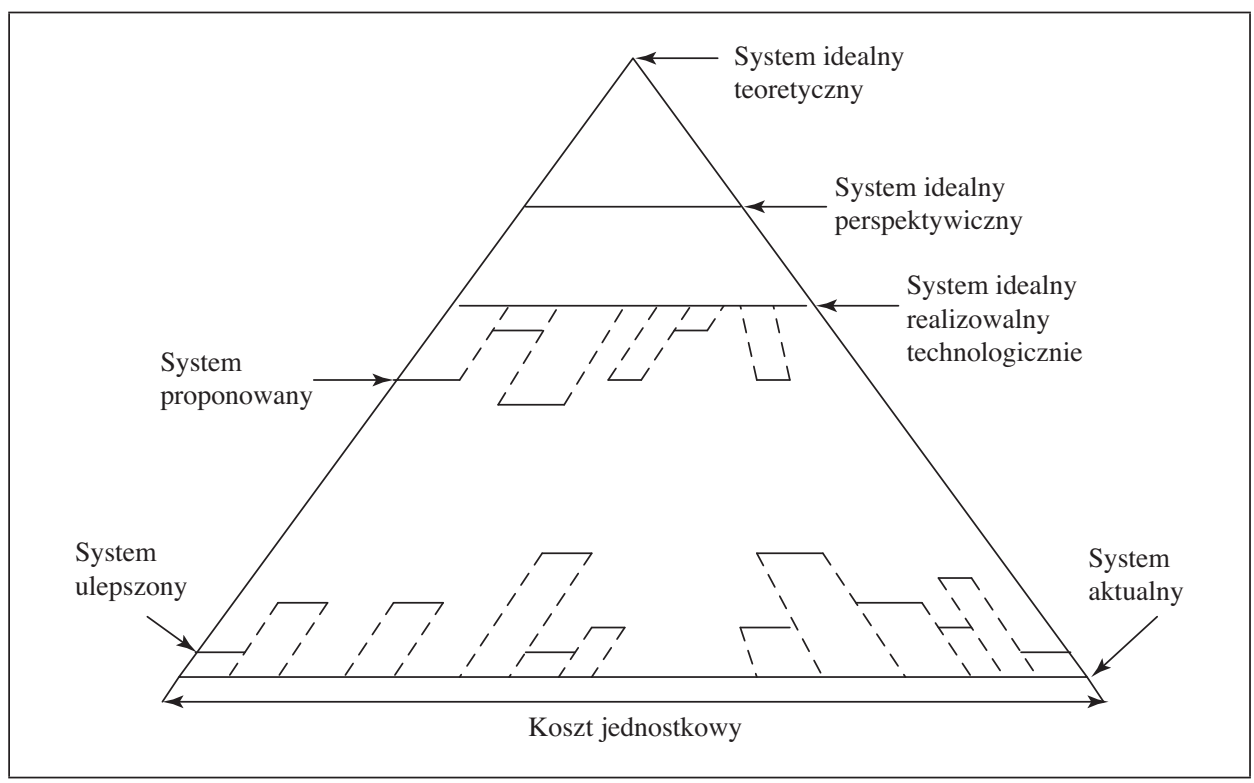

Rys. 1. Poziomy systemów idealnych według G. Nadlera Źródło: [Nadler 1967, s. 22].

Każdy z tych systemów różni się od pozostałych poziomem kosztów jednostkowych $w$ realizacji podstawowej funkcji systemu pracy, czyli dostarczania na rynek gotowych wyrobów lub usług, przy czym system idealny teoretyczny wyróżnia się zerowym poziomem kosztów (w warunkach idealnych), co w praktyce jest nieosiągalne. $Z$ kolei w następnych dwóch systemach idealnych (perspektywicznym oraz realizowalnym technologicznie) zwiększa się poziom kosztów, jak również możliwości praktycznego wykorzystania systemu w odnie- 
sieniu do konkretnej organizacji. W przypadku systemu idealnego perspektywicznego brak jego implementacji praktycznej wynika z ograniczeń naukowo-technicznych rozwiązań w chwili obecnej, na które należy poczekać od kilku do kilkunastu lat (np. na pojawienie się zaawansowanych technologii). Z kolei system idealny realizowalny technologicznie stanowi dalsze „pogarszanie” systemu oraz równoczesne zwiększanie kosztów funkcjonowania systemu pracy i opiera się na możliwości zastosowania najlepszych rozwiązań naukowo-technicznych dostępnych na rynku (np. rozwiązania te zostały zastosowane pomyślnie w organizacjach w kraju lub za granicą). Niemniej jednak nie każde rozwiązanie, które przyniosło pozytywne efekty w jednej organizacji, sprawdzi się w innej. Wymaga to dalszego urealniania systemu przez jego modyfikację, co prowadzi do zwiększenia kosztów jednostkowych z uwagi na rzeczywiste ograniczenia. W toku dostosowania systemu idealnego realizowalnego technologicznie powstaje system proponowany, który odpowiada dostępnym na rynku rozwiązaniom naukowo-technicznym oraz rzeczywistym możliwościom zasobowym konkretnego przedsiębiorstwa (zob. rys. 1).

Podsumowując, podstawę ,trójkąta Nadlera” stanowi aktualny system pracy charakteryzujący się relatywnie wysokimi kosztami jednostkowymi (zob. rys. 1). System ten w toku działań naprawczych może zostać usprawniony, co przedstawia system ulepszony. Zgodnie z założeniem koncepcji systemów idealnych G. Nadlera należy zaczynać od koncepcji idealnej systemu pracy i stopniowo zbliżać się do koncepcji uwzględniającej warunki ograniczające. Jest to podejście „schodzące” od góry w dół (top-down). Koncepcja ta może być stosowana w pracach nad doskonaleniem organizacji jako systemu w różnych obszarach. Stanowi ona również podstawę dalszego jej rozwoju i doskonalenia metodologicznego. Wynikiem tego rodzaju prac jest zmodyfikowana przez J. Trzcienieckiego metodyka oparta na podejściu funkcjonalno-wzorcującym, nazywana metodą prognostyczną [Czermiński i Trzcieniecki 1973, s. 136], w której zrezygnowano ze stopniowania systemów idealnych (przyjęty system wzorcowy odpowiada systemowi idealnemu perspektywicznemu w ujęciu G. Nadlera) czy późniejsze jej wersje. Tworzenie rozwiązań wzorcowych lub systemów idealnych często stanowi podstawę metodologiczną projektowania różnego rodzaju systemów organizacji (por. [Ackoff, Magidson i Addison 2007, Metodologia projektowania... 2015]). Szczególne znaczenie ma projektowanie tzw. elastycznych systemów organizacyjnych $^{1}$, stanowiących warunek konieczny dostosowywania się organizacji do

${ }^{1}$ Elastyczność może dotyczyć organizacji jako całości lub poszczególnych jej podsystemów czy elementów organizacyjnych (np. procesów, funkcji, zasobów lub metod zarządzania), uwzględniając specyfikę prowadzonej działalności (np. produkcja, usługi, handel, non-profit etc.) (zob. [Walecka i Zakrzewska-Bielawska 2013, s. 294]). 
zmieniających się uwarunkowań zewnętrznych [Volberda 1996, Morabito et al. 2009, Walecka i Zakrzewska-Bielawska 2013, Januszkiewicz i Jabłoński 2014].

Bazując na doświadczeniu tworzenia systemów idealnych pracy, można przyjąć, że koncepcja G. Nadlera stanowi użyteczne narzędzie również w przypadku tworzenia innych systemów idealnych istotnych z perspektywy rozwiązywania problemów zarządzania. Ponadto systemy te mieszczą się w apragmatycznej metodologii nauk o zarządzaniu, z uwagi na fakt, że są one wykorzystywane $\mathrm{w}$ teorii i nie mają zastosowania praktycznego, jak w przypadku systemów tworzonych na poziomie metodologii pragmatycznej.

\section{Charakterystyka modeli idealnych koncepcji doboru metod w rozwiązywaniu problemów zarządzania}

\subsection{Uwagi ogólne}

Różnorodne koncepcje występujące w naukach o zarządzaniu (zob. [Witczak 2014, s. 75]) pod wpływem zmian zachodzących w środowisku wewnętrznym i zewnętrznym organizacji tracą swoje właściwości poznawcze, co uniemożliwia skuteczne rozwiązywanie wyłaniających się nowych problemów zarządzania (zob. [Szarucki 2015]). Zwiększa się zatem potrzeba rozwoju i doskonalenia ${ }^{2}$ koncepcji zarządzania nastawionych na ich skuteczne rozwiązywanie [Lisiński 2010, s. 70]. Przez koncepcję rozumie się jednolity i spójny metodycznie tok postępowania badawczego, wyznaczający logiczny sposób rozwiązania podjętego problemu naukowego, uwzględniający metody stosowane na poszczególnych etapach określonych $w$ tym postępowaniu. Problem badawczy rozważany $\mathrm{w}$ niniejszym opracowaniu analizowany jest w ujęciu metodologii apragmatycznej $^{3}$ i wiąże się z charakterystyką cech modeli idealnych (według G. Nadlera) koncepcji doboru metod $\mathrm{w}$ rozwiązywaniu problemów zarządzania.

Podjęty problem badawczy, czyli to, na jakich zasadach dobierać metodę w procesie rozwiązywania problemu zarządzania, stanowi wyzwanie zarówno dla praktyków, jak i dla metodologów zarządzania. Dlatego jednym z kluczowych obszarów rozwoju w metodologii nauk o zarządzaniu jest opracowanie

2 Doskonalenie ma na celu takie przekształcenie obiektu, po którym zwiększa się efektywność jego funkcjonowania, co zapewnia skuteczniejszą realizację założonych celów. Jest ono niezmiernie ważne, ponieważ koncepcja ,powinna zapewniać racjonalny dobór metod zarządzania, uwzględniający sytuacyjne uwarunkowania organizacji, a także respektować reguły efektywności w toku ich praktycznych zastosowań” [Lisiński 2011b, s. 229].

3 Ten rodzaj metodologii dotyczy budowy teorii naukowych, dlatego jest on również określany mianem metodologii w aspekcie teoretycznym (por. [Ajdukiewicz 1975, s. 175; Snihur 2004, s. 8; Lisiński 2014, s. 138]). 
modelu doboru metod rozwiązywania problemów zarządzania [Lisiński 2013, s. 169]. Aktualność oraz ważność tego problemu naukowego wynika m.in. z następujących przesłanek płynących z teorii oraz praktyki nauk o zarządzaniu: problemy zarządzania ewoluują (co utrudnia proces doboru metod ich rozwiązywania), a menedżerowie często poświęcają zbyt mało uwagi kwestii doboru odpowiedniej metody w procesie rozwiązywania problemów ${ }^{4}$, brakuje wyczerpujących koncepcji metodologicznych mających na celu rozwiązanie wspomnianego problemu badawczego [Szarucki 2010, 2015, 2016a, 2016b, Lisiński 2011b, 2013].

Dużą zaletą koncepcji systemu idealnego jest to, że może być ona zastosowana do każdego rodzaju oraz stanu systemu - nowo tworzonego, działającego satysfakcjonująco lub działającego niesatysfakcjonująco. Ten ostatni stan może wystąpić w sytuacji kryzysu. Dlatego zaleca się budowanie jak najogólniejszego modelu idealnego systemu, który następnie może zostać wykorzystany jako źródło wskazówek w rozwiązywaniu zaistniałego problemu. Wśród różnych teorii systemowych koncepcja systemu idealnego G. Nadlera wykorzystywana do projektowania systemów organizacyjnych zakłada idealizowanie rozwiązań projektowych oraz tworzenie rozwiązań wzorcowych [Bartusik et al. 2015, s. 230]. Zdaniem autora niniejszego opracowania tego rodzaju podejście może być skutecznie zastosowane w tworzeniu koncepcji doboru metod w rozwiązywaniu problemów zarządzania.

Koncepcja doboru metod może być postrzegana jako metoda. $Z$ kolei metoda za T. Kotarbińskim może być rozpatrywana jako system postępowania, czyli „sposób wykonywania czynu złożonego, polegający na określonym doborze i układzie jego działań składowych, a przy tym uplanowiony i nadający się do wielokrotnego stosowania" [Kotarbiński 1969, s. 86-87]. Z uwagi na fakt, iż koncepcja stanowi metodę na najwyższym poziomie ogólności ${ }^{5}$, czyli poziomie filozoficznym, przyjęto, że podejście G. Nadlera (zob. rys. 1) może zostać wykorzystane do tworzenia modeli idealnych koncepcji doboru metod w rozwiązywaniu problemów zarządzania (zob. rys. 2). Modele idealne koncepcji doboru metod mieszczą się w metodologii apragmatycznej nauk o zarządzaniu, a metody

${ }^{4} \mathrm{~W}$ organizacjach w trakcie rozwiązywania problemów zarządzania brakuje wiedzy, iż „dobór metody jest kompromisem pomiędzy gotowością i zdolnością organizacji do sprawnego rozwiązywania problemów, z jednej strony, oraz znajomością i umiejętnością praktycznego wykorzystania metod zarządzania, z drugiej” [Lisiński 2011b, s. 228].

${ }^{5}$ Wspomniana koncepcja będzie utożsamiana z filozofią, orientacją bądź podejściem i znajduje się na poziomie najogólniejszym, czyli pierwszym. Pozostałe dwa poziomy umieszczone zgodnie z malejącym stopniem ogólności dotyczą metody ogólnej (poziom drugi) oraz metody szczegółowej, technik i narzędzi (poziom trzeci) - por. [Jagoda i Lichtarski 2003, s. 3]. 


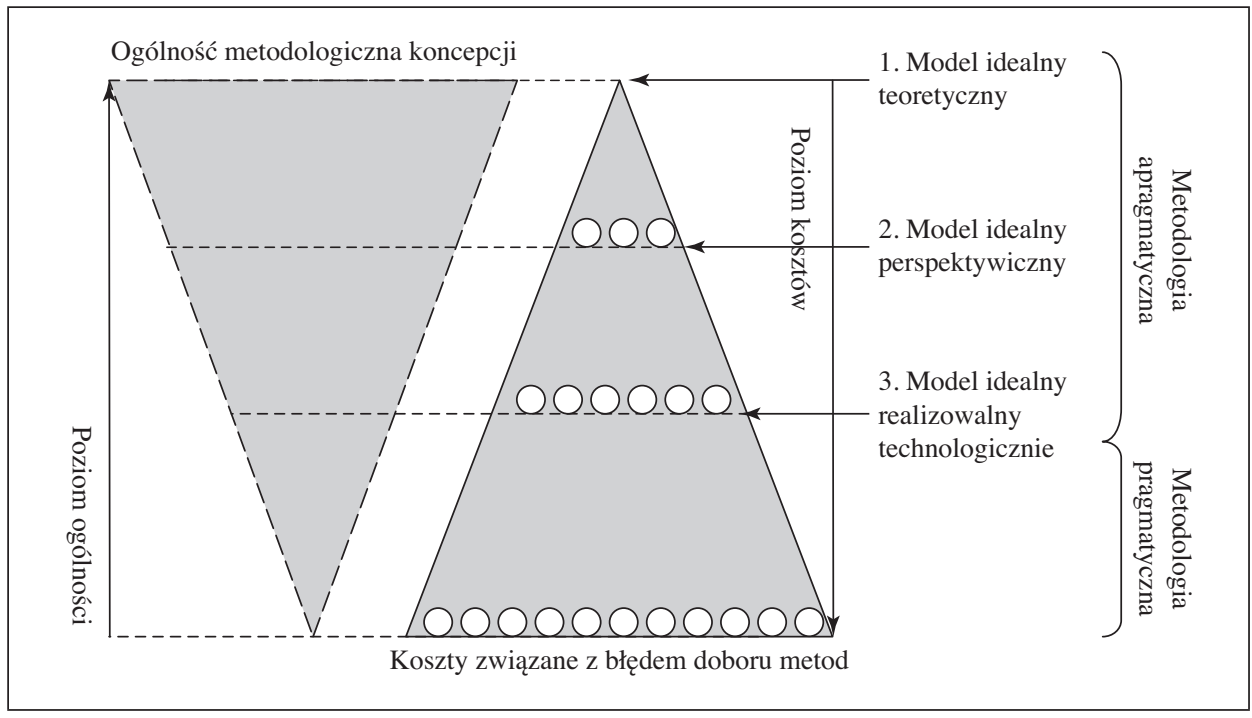

Rys. 2. Modele idealne koncepcji doboru metod w rozwiązywaniu problemów zarządzania

Źródło: opracowanie własne.

stosowane w praktyce znajdują się na poziomie metodologii pragmatycznej (zob. rys. 2).

\subsection{Model idealny teoretyczny koncepcji doboru metod}

W tym punkcie omówione zostały zasadnicze różnice pomiędzy trzema proponowanymi idealnymi modelami koncepcji doboru metod w rozwiązywaniu problemów zarządzania.

Proponowany w niniejszym artykule model idealny teoretyczny koncepcji doboru metod w rozwiązywaniu problemów zarządzania odpowiada klasycznemu systemowi idealnemu teoretycznemu według G. Nadlera. Znajduje się on na samym szczycie trójkąta ze względu na spełnianie warunków wynikających z dwóch proponowanych kryteriów podziału modeli idealnych (zob. rys. 2): poziomu ogólności i poziomu kosztów. Poziom ogólności metodologicznej koncepcji doboru metod w rozwiązywaniu problemów zarządzania uwzględnia w sobie wiedzę należącą do czterech działów filozofii nauki w obszarze dyscypliny nauk o zarządzaniu, a mianowicie: epistemologii, ontologii, metodologii i aksjologii nauk o zarządzaniu [Litzinger i Schaeffer 1966, Steffy i Grimes 1986, Mingers 2003, Lisiński 2011a, Sułkowski 2012, Kuc 2015]. Wiedza ta ma swe źródła w filozofii nauki i jest traktowana dosyć szeroko, na tyle, że w modelu idealnym teoretycznym koncepcji doboru tworzy ona taką spójną i logiczną 
całość, która zakłada dobieranie metod w trakcie rozwiązywania problemów zarządzania w sposób doskonały (jedna metoda, która idealnie pasuje do rozwiązania problemu zarządzania). Określenie „doskonały” na poziomie metodologii apragmatycznej oznacza: niemający zastosowania w praktyce. Doskonałość tego sposobu doboru metod jest mierzona stopniem osiągnięcia założonego celu (lub celów) oraz brakiem kosztów ${ }^{6}$ towarzyszących temu procesowi niezależnie od liczby i natury rozwiązywanych problemów zarządzania. Całkowity brak kosztów wynikających z błędu doboru odpowiedniej metody do nieograniczonej liczby rozwiązywanych problemów zarządzania pozwala model ten utożsamić z nieskończonością matematyczną. Należy podkreślić, że pojęcie wspomnianych kosztów, jakimi się operuje w metodologii apragmatycznej nauk o zarządzaniu, jest inne niż to przedstawione wcześniej w oryginalnym podejściu G. Nadlera. W oryginalnej koncepcji systemów idealnych koszty dotyczą wytwarzanych jednostek (wyrobów) uzyskiwanych na wyjściu z systemu. W przypadku teoretycznego modelu idealnego koncepcji metodologicznej jest to doskonałe funkcjonowanie polegające na idealnym dobieraniu metod do rozwiązywanych problemów zarządzania niezależnie od ich liczby, złożoności czy zasięgu występowania w organizacji. W modelu tym zakłada się brak występowania ograniczeń teoretyczno-metodologicznych, które uniemożliwiłyby optymalny dobór metod w rozwiązywaniu problemu zarządzania.

Głównym celem modelu idealnego zlokalizowanego na najwyższym poziomie jest zapewnienie możliwie najszerszego zakresu dla prowadzonych badań oraz zlikwidowanie ograniczeń w procesie rozważań nad opracowaniem odpowiedniej koncepcji doboru metod w rozwiązywaniu problemów zarządzania. Proces ten w głównej mierze opiera się na metodzie dedukcyjnej, w której toku tworzone są tezy na podstawie istniejącej sprawdzonej empirycznie wiedzy teoretycznej ${ }^{7}$. Główną wartość modelu idealnego teoretycznego koncepcji doboru metod w rozwiązywaniu problemów zarządzania stanowi jego ukierunkowanie na proces nieustannego usprawniania i dostosowywania koncepcji doboru do wyzwań metodologicznych, które będą się wyłaniać w przyszłości. Niemniej jednak model idealny teoretyczny, który zakłada zerowe koszty dla uzyskania nieograniczonego wyniku, stanowi sam w sobie pewne ograniczenie, które nie pozwala na jego całkowite osiągnięcie. Dlatego model ten stosowany jest na

${ }^{6}$ Brak kosztów związanych z nieodpowiednim doborem metody rozwiązywania problemu zarządzania.

7 Takie podejście badawcze jest stosowane w przypadku dedukcyjnej metody tworzenia teorii. Stosując określone założenia idealizacyjne, można wyprowadzać proste teorie z nagromadzonej już wiedzy teoretycznej. Zdaniem L. Nowaka, jeżeli „wyjściowa wiedza teoretyczna została już sprawdzona empirycznie, to oczekiwać można, że wyprowadzona z niej prosta teoria idealizacyjna będzie w nie gorszym stopniu zgodna z faktami” [Nowak 1977, s. 115]. 
poziomie definicyjnym w odróżnieniu od poziomu operacyjnego. Prowadzi to do kontynuacji badań nad modelem idealnym koncepcji doboru na poziomie drugim, o mniejszej ogólności metodologicznej oraz większym pod względem operacyjności w stosunku do modelu idealnego teoretycznego.

\subsection{Model idealny perspektywiczny koncepcji doboru metod}

Następstwem uszczegóławiania modelu idealnego teoretycznego koncepcji doboru metod jest opracowanie modelu idealnego perspektywicznego tejże koncepcji. W przypadku oryginalnego systemu idealnego perspektywicznego (ultimate ideal system) opracowanego przez G. Nadlera występują określone koszty uzyskania wyników w odróżnieniu od systemu idealnego teoretycznego, gdzie tego rodzaju koszty jednostkowe nie występują [Nadler 1967, s. 26]. Dlatego też w proponowanym modelu idealnym perspektywicznym koncepcji doboru metod w rozwiązywaniu problemów zarządzania pojawiają się pewne koszty (na rys. 2 przedstawiono je w postaci białych kółek) związane z błędami doboru metod w rozwiązywaniu problemów zarządzania. Są one następstwem zmniejszenia się poziomu ogólności metodologicznej koncepcji, czyli zwiększa się liczba potencjalnych metod, które mogą zostać z powodzeniem zastosowane w koncepcji doboru. Model ten jest perspektywiczny, gdyż uwzględnia długoterminową perspektywę, czyli okres, w jakim odpowiednie nowe metody zostaną stworzone (obecnie jeszcze ich nie ma) lub te dostępne zostaną zmodyfikowane (obecnie nie są one dostosowane do występujących warunków wewnętrznych i zewnętrznych). Zatem model ten jest modelem pożądanym i przedstawia przewidywaną metodykę doboru metod, uwzględniając zasadnicze czynniki wpływające na proces doboru. Perspektywiczność tego modelu uwarunkowana jest brakiem możliwości jego zastosowania praktycznego w danym momencie ze względu na brak dostępnych rozwiązań metodologicznych. Jego praktyczne zastosowanie może nastąpić dopiero w momencie, gdy w toku prowadzonych badań dostarczone zostaną stosowne informacje i metody badawcze.

Model idealny perspektywiczny koncepcji doboru metod zawierać może następujące problemy metodologiczne: Jak ustalić kryteria oceny metod rozwiązywania problemów zarządzania? Jak dokonać oceny metod i zbudować ich ranking? Jak dokonać wyboru metody? Jaką postać powinno mieć sprzężenie zwrotne (oraz sprzężenie następcze) w celu zapewnienia największej skuteczności doboru metod? W przeciwieństwie do modelu idealnego teoretycznego, w modelu idealnym perspektywicznym poziom ogólności metodolologicznej jest mniejszy, czyli jest na poziomie metody, która pozwala w idealnych warunkach rozwiązać wymienione przykładowe problemy metodologiczne. Dlatego też teoretycznie model ten można stosować na poziomie operacyjnym jako wzorzec, pod warun- 
kiem dostępu do odpowiednich rozwiązań metodologicznych. Niemniej jednak stanowi on przede wszystkim podstawę do opracowania następnego, bardziej szczegółowego pod względem metodologicznym modelu idealnego realizowalnego technologicznie.

\subsection{Model idealny realizowalny technologicznie koncepcji doboru metod}

Trzeci model, czyli model idealny realizowalny technologicznie koncepcji doboru metod w rozwiązywaniu problemów zarządzania, stanowi odzwierciedlenie systemu idealnego realizowalnego technologicznie według G. Nadlera. Model ten jest wypadkową przekształceń metodologicznych poprzednich dwóch modeli idealnych, znajduje się na trzecim, najniższym poziomie ogólności metodologicznej, a koszty związane z błędem doboru metod są w nim najwyższe (liczba białych kółek rośnie, zob. rys. 2). Model ten byłby możliwy do zastosowania w praktyce pod warunkiem braku występowania ograniczeń związanych z doborem dostępnych metod rozwiązywania problemów zarządzania. Zazwyczaj tego rodzaju model zawiera w sobie systemy informacyjno-decyzyjne pozwalające bezbłędnie analizować wszystkie informacje w zakresie rozwiązywanego problemu oraz dokonywać wyboru odpowiednich metod. Model ten ze względu na większą szczegółowość metodologiczną w odróżnieniu od poprzednich dwóch modeli idealnych zakłada w swojej istocie dostosowywanie dostępnych metod do rozwiązywanych problemów zarządzania. Niemniej jednak w procesie adaptacji metod pojawiają się dodatkowe koszty wynikające z potencjalnego błędu niedostosowania w stu procentach metody do problemu.

Pośród trzech modeli idealnych model ten, choć o charakterze apragmatycznym znajduje się najbliżej modeli realizowanych praktycznie. Należy pamiętać, że każda konkretna sytuacja problemowa w organizacji narzuca prawie zawsze jakieś specyficzne ograniczenia metodologiczne. Dlatego model idealny realizowalny technologicznie koncepcji doboru metod w rozwiązywaniu problemów zarządzania wymaga stosownej jego modyfikacji w celu adaptacji do warunków praktycznych. Modyfikacje mogą dotyczyć stosowania konkretnych sposobów doboru metod rozwiązywania problemów zarządzania należących do poszczególnych grup lub rodzin (np. metod analizy otoczenia, formułowania prognoz rozwoju sytuacji czy określania misji i celów organizacji) - zob. [Szarucki 2013, 2014b] - lub projektowania systemu ustalania kryteriów oceny tychże metod rozwiązywania problemów zarządzania [Szarucki 2014a]. Występuje też możliwość zwiększenia funkcjonalności tego modelu poprzez zastosowanie odpowiednich algorytmów o charakterze kaskadowym [Newstrom i Pierce 1990; Szarucki 2016b, s. 147]. Kaskadowość algorytmów doboru metod pozwala dokonywać oceny metod i zawęzić ich liczbę do grupy metod najbardziej 
adekwatnych w danych warunkach do rozwiązywanego problemu zarządzania ${ }^{8}$. Model idealny realizowalny technologicznie znajduje się zatem najniżej w hierarchii metodologii apragmatycznej nauk o zarządzaniu, co przybliża go do modelu koncepcji realizowalnej praktycznie w konkretnej organizacji, mieszczącej się już w metodologii pragmatycznej nauk o zarządzaniu. Praktyczną adaptację tego modelu idealnego determinują czynniki charakteryzujące konkretną organizację, jak również środowisko zewnętrzne, w którym ona funkcjonuje.

Podsumowując, zaprezentowane modele idealne koncepcji doboru metod w rozwiązywaniu problemów zarządzania mają określone atuty w odróżnieniu od koncepcji nastawionych na doskonalenie istniejących systemów, tzw. tradycyjnych modeli doboru metod. Modele koncepcji według G. Nadlera pozwalają od samego początku zaprojektować system doboru metod, który najpełniej realizuje swoje funkcje. Na bazie tych modeli tworzone są systemy, które mogą zostać zastosowane praktycznie w konkretnej organizacji. Trzy poziomy modeli idealnych koncepcji umożliwiają szerokie bądź wąskie wyznaczenie ram metodologicznych tworzenia systemu doboru metod w rozwiązywaniu problemów zarządzania. Ważną cechą modeli idealnych koncepcji doboru metod jest ich nieustanna adaptowalność do zmieniających się warunków wewnętrznych i zewnętrznych organizacji, jak również do zmian w metodologii pragmatycznej i apragmatycznej nauk o zarządzaniu [Lisiński 2013, 2016a]. Modele idealne koncepcji doboru metod mają charakter stopniowego uszczegółowiania metodyki badawczej oraz uwzględniają założenia modeli wyższego poziomu (np. model idealny perspektywiczny wynika z modelu idealnego teoretycznego, a model idealny realizowalny technologicznie zawiera w sobie elementy poprzednich modeli idealnych wyższego poziomu).

Modele idealne koncepcji doboru metod w rozwiązywaniu problemów zarządzania uwzględniają w swojej budowie dorobek teoretyczno-metodologiczny nauk o zarządzaniu. Jest on wykorzystywany zgodnie z celem budowy modelu koncepcji i bazuje na dorobku wszystkich podejść metodologicznych ${ }^{9}$ zawierają- $^{-}$ cych $\mathrm{w}$ sobie powstałe $\mathrm{w}$ ich ramach nurty metodologiczne ${ }^{10}$ nauk o zarządzaniu [Lisiński 2011a, s. 34-39]. Nurty metodologiczne, utożsamiane z postawą metodo-

${ }^{8}$ Kaskadowość jest efektem stopniowego „schodzenia”, ,zstępowania” z poziomu wyższego analizowanych metod rozwiązywania problemów zarządzania (bardziej ogólnego) na poziomy niższe (bardziej szczegółowe). Można ją wyrazić w postaci odpowiednich „okien” (por. [Newstrom i Pierce 1990]).

9 Podejście metodologiczne stanowi dominującą w danym okresie orientację metodologiczną. Jego cechą szczególną są jego relacje z organizacją, jako obiektem doskonalenia. M. Lisiński wyróżnia pięć podejść metodologicznych: klasyczne, organizacyjne, mechanistyczne, organiczne oraz współczesne [Lisiński 2011a, s. 31].

10 Nurt metodologiczny to spójna wewnętrznie postawa metodologiczna, która opiera się na założeniach teoretycznych, wyraża określone preferencje badawcze oraz eksponuje szczególny wgląd w istotny dla tego nurtu obszar problemowy [Lisiński 2011a, s. 30]. 
logiczną, tworzą szczególną perspektywę badawczą i zawierają w sobie kluczowe metodologiczne wartości niezbędne dla sprawnego rozwiązywania problemów zarządzania. Tę postawę metodologiczną czy perspektywę badawczą stanowią paradygmaty metodologiczne nauk o zarządzaniu [Lisiński 2016c]. Modele idealne koncepcji doboru metod nie stanowią zastygłej formy ${ }^{11}$, podlegają samodoskonaleniu, opierając się na panującym w naukach o zarządzaniu pluralizmie metodologicznym [Brannen 1992, s. 3-37; Jackson 1999, s. 12-22; Sułkowski 2015, s. 35], polegającym na łączeniu różnorodnych metod badawczych mających na celu idealną realizację funkcji koncepcji. Tendencja do wykorzystania metod z różnych nurtów oraz mieszanie się reguł oraz zasad metodologicznych jest charakterystyczne dla ostatniego z identyfikowanych podejść metodologicznych - podejścia współczesnego [Lisiński 2011a, s. 41] $]^{12}$.

\section{Uwagi końcowe}

System idealny G. Nadlera stanowi metodologiczną koncepcję doskonalenia funkcjonowania organizacji. W opinii autora niniejszego opracowania podejście to wykorzystać można również w tworzeniu modeli idealnych w apragmatycznej metodologii nauk o zarządzaniu. Do takich modeli należy model koncepcji doboru metod w rozwiązywaniu problemów zarządzania. Modele te tworzone są z zastosowaniem metody dedukcyjnej i sprawdzonych danych teoretycznych. Zaprezentowana charakterystyka trzech modeli idealnych wspomnianej koncepcji częściowo wypełnia zidentyfikowaną lukę poznawczą dotyczącą istotnego problemu naukowego, jakim jest dobór metod w rozwiązywaniu problemów zarządzania. Przeprowadzona analiza stanowi oryginalny wkład w rozwój apragmatycznej metodologii nauk o zarządzaniu. Ten wkład odnieść można do trzech zakresów: teoretycznego, metodologicznego oraz praktycznego.

W zakresie teoretycznym modele idealne koncepcji doboru metod stanowią próbę wykorzystania i adaptacji koncepcji systemu idealnego G. Nadlera.

${ }^{11}$ Koncepcja systemu idealnego według G. Nadlera łączy w sobie dwie filozofie zmiany, mianowicie: rewolucyjną oraz ewolucyjną [Nadler 1967, s. 28]. Dlatego koncepcja doboru metod w rozwiązywaniu problemów zarządzania powinna być maksymalnie doskonała od samego początku (filozofia rewolucyjna). Niemniej jednak dopuszczane jest wprowadzanie ciągłych zmian usprawniających (filozofia ewolucyjna).

12 Podejście to stanowi metodologiczny kolaż, swoistą mieszaninę „,metod (od przekrojowych koncepcji zarządzania, poprzez zasady, metody, na poszczególnych technikach kończąc), szczególnego kontekstu i różnego wpływu paradygmatów metodologicznych, kluczowych i dominujących czynników zarówno otoczenia zewnętrznego, jak i środowiska wewnętrznego organizacji, a także podstawowych obszarów badawczych i relacji między nimi, występujących w dwóch ostatnich dekadach rozwoju metodologii zarządzania" [Lisiński 2011a, s. 41-42]. 
W kwestii metodologicznej propozycja modeli idealnych koncepcji doboru metod wzbogaca metodologię apragmatyczną nauk o zarządzaniu o nowe, niespotykane dotychczas w literaturze przedmiotu wykorzystanie podejścia metodologicznego G. Nadlera. Propozycja ta służy również doskonaleniu metodologii pragmatycznej, ponieważ inspiruje do tworzenia metod mających bezpośrednie zastosowanie w praktyce zarządzania. Choć koncepcja doboru metod w rozwiązywaniu problemów zarządzania nie ma bezpośredniego wpływu na praktykę zarządzania, to zdaniem autora tego rodzaju koncepcje idealne mogą zainteresować wysokiej rangi kadrę menedżerską, stanowiąc inspirację do ich twórczej adaptacji dla potrzeb praktyki gospodarczej.

Podsumowując przedstawione rozważania, zaznaczyć należy, iż scharakteryzowane modele idealne koncepcji doboru metod w rozwiązywaniu problemów zarządzania nie stanowią ostatecznego rozwiązania i wymagają szerszej dyskusji wśród praktyków i metodologów zarządzania w celu ich dalszego doskonalenia.

\section{Literatura}

Ackoff R.L., Magidson J., Addison H.J. [2007], Projektowanie ideatu. Kształtowanie przyszłości organizacji, Wydawnictwa Akademickie i Profesjonalne, Warszawa.

Ajdukiewicz K. [1975], Logika pragmatyczna, PWN, Warszawa.

Bartusik K., Ćwiklicki M., Mesjasz C., Sołtysik M. [2015], Podejście systemowe w projektowaniu organizacji [w:] Metodologia projektowania systemów organizacyjnych przedsiębiorstwa, red. A. Stabryła, C.H. Beck, Warszawa.

Brannen J. [1992], Combining Qualitative and Quantitative Approaches: An Overview [w:] Mixing Methods: Qualitative and Quantitative Research, ed. J. Brannen, Avebury, Aldershot.

Bratnicki M., Frączkiewicz-Wronka A. [2006], Efektywność organizacyjna i zarzadzanie publiczne - wytaniajace się koncepcje, kluczowe wyzwania i kierunki dalszych badań w obszarze pomiaru efektywności, „Organizacja i Kierowanie”, nr 3.

Cameron K.S., Whetten D.A. [1996], Organizational Effectiveness and Quality: The Second Generation, „Higher Education: Handbook of Theory and Research”, nr 11.

Czermiński A., Trzcieniecki J. [1973], Elementy teorii organizacji i zarzadzania, PWN, Warszawa.

Jackson M.C. [1999], Towards Coherent Pluralism in Management Science, „Journal of the Operational Research Society", vol. 50, nr 1, https://doi.org/10.1057/palgrave. jors.2600661.

Jagoda H., Lichtarski J. [2003], O istocie i ewolucji współczesnych koncepcji i metod zarzadzania przedsiębiorstwem, „Przegląd Organizacji”, nr 1.

Januszkiewicz K., Jabłoński M. [2014], Elastyczność organizacji i jednostki w gospodarce opartej na wiedzy, Acta Universitatis Lodziensis. Folia Oeconomica, nr 4(304).

Kotarbiński T. [1969], Traktat o dobrej robocie, wyd. 4, Zakład Narodowy im. Ossolińskich, Wrocław.

Kuc B.R. [2015], Aksjologia organizacji i zarządzania: na krawędzi kryzysu wartości, Ementon, Warszawa. 
Lisiński M. [2010], Model formułowania współczesnych koncepcji zarządzania [w:] Osiagnięcia i perspektywy nauk o zarzadzaniu, red. S. Lachiewicz, B. Nogalski, Wolters Kluwer Polska, Warszawa.

Lisiński M. [2011a], Analiza metodologii nauk o zarządzaniu [w:] Rozwój koncepcji i metod zarządzania, red. J. Czekaj, M. Lisiński, Fundacja Uniwersytetu Ekonomicznego w Krakowie, Kraków.

Lisiński M. [2011b], Metodologia nauk o zarzadzaniu a sukces organizacji, Prace i Materiały Wydziału Zarządzania Uniwersytetu Gdańskiego, nr 4/2, Sopot.

Lisiński M. [2013], Współczesne problemy rozwoju metodologii nauk o zarządzaniu, „Zarządzanie i Finanse”, cz. 1, nr 4.

Lisiński M. [2014], Metodologia apragmatyczna nauk o zarządzaniu, „Organizacja i Kierowanie", $\mathrm{nr} 1 \mathrm{~A}$ (159).

Lisiński M. [2016a], Metodologia pragmatyczna nauk o zarządzaniu, „Zarządzanie i Finanse" cz. 1, nr 2.

Lisiński M. [2016b], Metody naukowe w metodologii nauk o zarządzaniu, „Przegląd Organizacji”, nr 4.

Lisiński M. [2016c], Paradygmaty metodologiczne nauk o zarzadzaniu, „Prace Naukowe Uniwersytetu Ekonomicznego we Wrocławiu", nr 421, https://doi.org/10.15611/ pn.2016.421.31.

Litzinger W.D., Schaeffer T.E. [1966], Perspective: Management Philosophy Enigma, „Academy of Management Review”, vol. 9, nr 4, https://doi.org/10.2307/254952.

Martyniak Z. [1987], Organizatoryka, PWE, Warszawa.

Martyniak Z. [2000], Efektywność organizacji, „Ekonomika i Organizacja Przedsiębiorstwa", nr 11.

Metodologia projektowania systemów organizacyjnych przedsiębiorstwa [2015], red. A. Stabryła, C.H. Beck, Warszawa.

Mingers J. [2003], A Classification of the Philosophical Assumptions of Management Science Methods, ,Journal of the Operational Research Society”, vol. 54, https://doi. org/10.1057/palgrave.jors.2601436.

Morabito J., Sack I., Stohr E.A., Bhate A. [2009], Designing Flexible Organizations, „Global Journal of Flexible Systems Management”, vol. 10, nr 2.

Nadler G. [1967], Work Systems Design: The Ideals Concept, Irwin, Homewood.

Nalewajko E. [1983], Niektóre teoretyczne ujęcia efektywności organizacyjnej (studium literatury), „Organizacja i Kierowanie”, nr 1.

Newstrom J.W., Pierce J.L. [1990], Windows into Organizations, Amacom, New York.

Nowak L. [1977], Wstep do idealizacji teorii nauki, PWN, Warszawa.

Piekarz H., Stabryła A. [1989], Analiza efektywności organizacyjnej jako narzędzie wspomagania procesu zarzadzania, Zeszyty Naukowe Uniwersytetu Gdańskiego, nr 12.

Snihur S. [2004], Elementarne zagadnienia logiki, Wydawnictwo SGGW, Warszawa.

Steffy B.D., Grimes A.J. [1986], A Critical Theory of Organization Science, „Academy of Management Review", vol. 11, nr 2, https://doi.org/10.5465/amr.1986.4283115.

Sułkowski Ł. [2012], Epistemologia i metodologia zarzadzania, PWE, Warszawa.

Sułkowski Ł. [2015], Metodologia zarzadzania - od fundamentalizmu do pluralizmu [w:] Podstawy metodologii badań w naukach o zarządzaniu, red. W. Czakon, wyd. 3 rozsz., Wolters Kluwer, Warszawa.

Szarucki M. [2010], Przesłanki wyboru metod rozwiąywania problemów zarzadzania [w:] Dylematy zarządzania organizacjami we wspótczesnej gospodarce, red. A. Adamik, S. Lachiewicz, Wydawnictwo Politechniki Łódzkiej, Łódź. 
Szarucki M. [2013], Dobór instrumentów formułowania i implementacji strategii, Zeszyty Naukowe Uniwersytetu Przyrodniczo-Humanistycznego w Siedlcach, Seria: Administracja i Zarządzanie, nr 97(24).

Szarucki M. [2014a], System ustalania kryteriów oceny w modelu doboru metod rozwiazywania problemów zarządzania, Acta Universitatis Lodziensis. Folia Oeconomica, $\mathrm{nr}$ 4(305).

Szarucki M. [2014b], Typologia metod rozwiązywania problemów zarządzania, „Marketing i Rynek", nr 5.

Szarucki M. [2015], Evolution of Managerial Problems from the Perspective of Management Science, ,Business: Theory and Practice”, vol. 16, nr 4, https://doi.org/10.3846/ btp.2015.684.

Szarucki M. [2016a], Dylematy praktyczne rozwiąywania problemów zarzadzania w opinii menedżerów [w:] Stan i perspektywy rozwoju nauk o zarządzaniu, red. A. Zakrzewska-Bielawska, Dom Organizatora TNOiK, Toruń.

Szarucki M. [2016b], Koncepcja doboru metod w rozwiąywaniu problemów zarzadzania, Zeszyty Naukowe Uniwersytetu Ekonomicznego w Krakowie, Seria specjalna: Monografie, nr 247, Kraków.

Volberda H.W. [1996], Toward the Flexible Form: How to Remain Vital in Hypercompetitive Environments, „Organization Science”, vol. 7, $\mathrm{nr} 4$, https://doi.org/10.1287/ orsc.7.4.359.

Walecka A., Zakrzewska-Bielawska A. [2013], Organizacja $w$ procesach zmian $-w$ drodze do elastyczności i innowacyjności [w:] Nauka o organizacji. Ujęcie dynamiczne, red. A. Adamik, Oficyna Wolters Kluwer, Warszawa.

Witczak H. [2014], Wstęp do naukowego statusu koncepcji zarządzania, „Organizacja i Kierowanie", nr 2(162).

Ziębicki B. [2014], Efektywność organizacyjna podmiotów sektora publicznego, Zeszyty Naukowe Uniwersytetu Ekonomicznego w Krakowie, Seria specjalna: Monografie, nr 234.

\section{Nadler-based Models of Method Selection in Management Problem-solving (Abstract)}

Increasing organisational efficiency as a category of management sciences is one of the major challenges for both practitioners and theoreticians of management. Properly selecting methods to solve management problems is one factor that increases organisational efficiency. However, there is a lack of extensive methodological studies addressing method selection in the process of management problem solving. Nadler's concept of the ideal system may serve as the basis for constructing method selection. The main objective of this study is to present the possibilities of adapting Nadler's concept in creating the models of method selection in management problem-solving. Deduction and an analysis of the literature were the research methods employed. The article begins by exemplifying Nadler's concept of an ideal system. This is followed by an original proposal for ideal models of method selection in management problem-solving. Finally, conclusions and suggestions for further research are discussed.

Keywords: ideal system, method selection, management problems, Nadler's concept. 